\title{
Efficacy of Lagenidium giganteum (Couch) metabolites for control Anopheles stephensi (Liston) a malaria vector
}

\author{
Gavendra Singh*, Soam Prakash \\ From Parasite to Prevention: Advances in the understanding of malaria \\ Edinburgh, UK. 20-22 October 2010
}

\section{Background}

Lagenidium giganteum (Couch) a water mold of class Oomy-cetes, is a facultative parasite of mosquito. The metabolites of L. giganteum were tested for control of Anopheles stephensi. This fungus was grown in Peptone yeast extract glucose (PYG) broth in the laboratory at 25 $\pm 2^{\circ} \mathrm{C}$, and relative humidity was maintained at $75 \pm 5 \%$ for $15 \pm 2$ days. The filtration process of metabolites was done using Whatman-1 filter paper and then with Flash chromatography. These purified metabolites were spray at five $\left(3,4,5,6,7 \mathrm{ml} / \mathrm{m}^{2}\right)$ different statistically significant concentrations. The efficacy after whatman- 1 the $\mathrm{LC}_{50}-5 \mathrm{ml} / \mathrm{m}^{2}$, $\mathrm{LC}_{90}-7.07 \mathrm{ml} / \mathrm{m}^{2}$ and $\mathrm{LC}_{99}-10 \mathrm{ml} / \mathrm{m} 2$ values were found effective after exposure of $15 \mathrm{~h} . \mathrm{LT}_{50^{-}}-10.23 \mathrm{~h}$ and $\mathrm{LT}_{90^{-}}$ $16.59 \mathrm{~h}$ were recorded. Similarly, efficacy after Flash chromatography the $\mathrm{LC}_{50^{-}} 4 \mathrm{ml} / \mathrm{m}^{2}, \mathrm{LC}_{90^{-}}-6 \mathrm{ml} / \mathrm{m}^{2}$ and $\mathrm{LC}_{99^{-}}$ $6.76 \mathrm{ml} / \mathrm{m} 2$ values were found effective after exposure of 15h. The $\mathrm{LT}_{50^{-}}-6.16 \mathrm{~h}$ and $\mathrm{LT}_{90}-12.02 \mathrm{~h}$ were observed. This study reveals the metabolites of L.giganteum could be used for control of An. stephensi a malaria vector. Figures 1, 2, 3

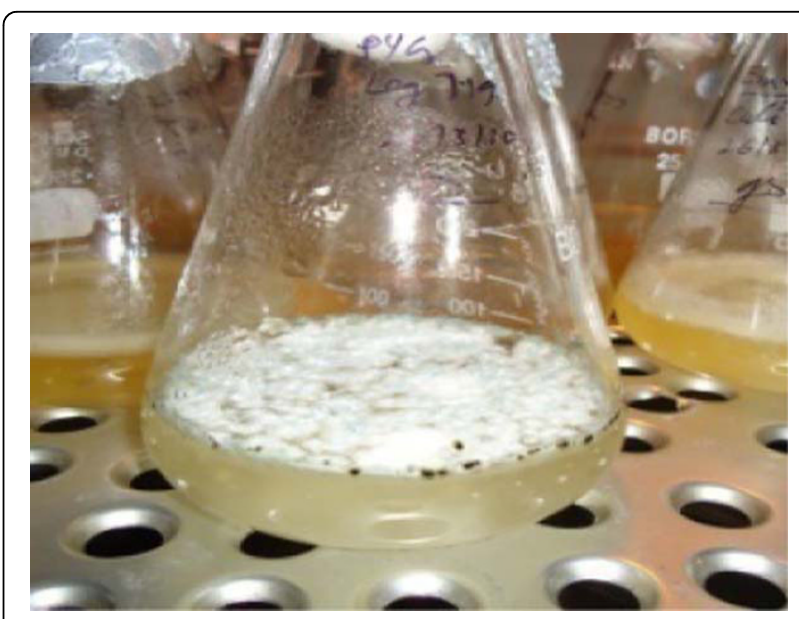

Figure 1 The culture of L. giganteum in Peptone yeast extract glucose (PYG) broth in the laboratory.

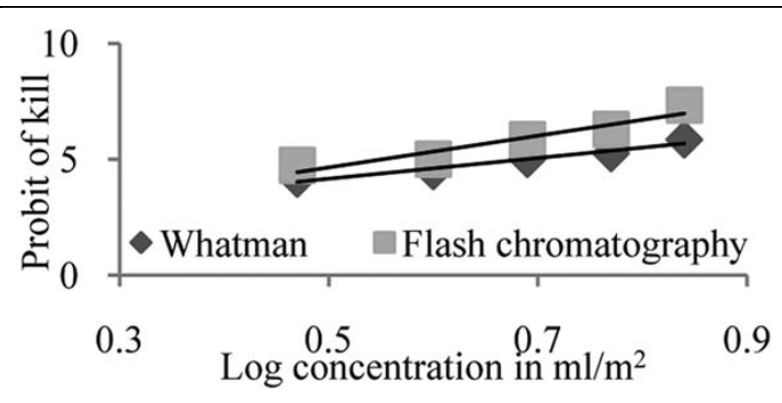

Figure 2 Probit regression line depicting relationship between probit of kill and log dose concentrations of metabolites of $L$. giganteum after $15 \mathrm{~h}$ exposure for An. stephensi.

Environmental and Advanced Parasitology and Vector Control Biotechnology Laboratories, Department of Zoology, Dayalbagh Educational Institute,

Dayalbagh, Agra-282 005, India

Full list of author information is available at the end of the article

(c) 2010 Singh and Prakash; licensee BioMed Central Ltd. This is an open access article distributed under the terms of the Creative 


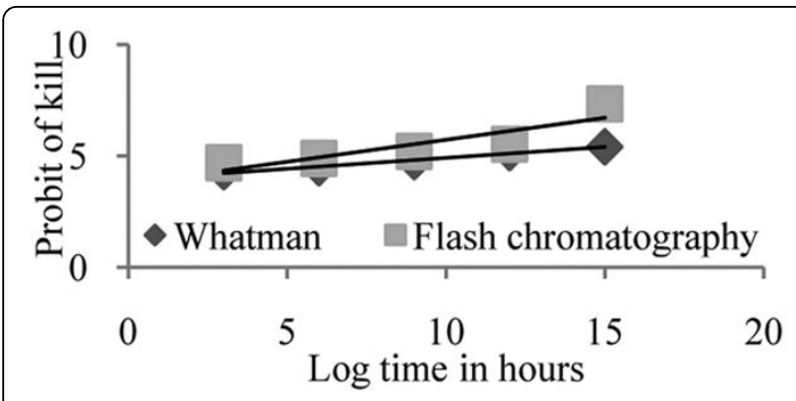

Figure 3 Probit regression line depicting relationship between probit of kill and log time of L. giganteum for An. stephensi.

significant pathogenicity against the larvae of An. stephensi in laboratory (Prakash et al. 2010). Regardless, the use of fungi L. giganteum to control population of An. stephensi mosquitoes clearly offers significant promise as a novel biologically based strategy to be integrated with other control measures to reduce global rate of malaria transmission. Also Scholte et al. (2005) have used fungal spores as adulticidal to control vector population in African villages, so fungal metabolites can be used as novel liquid adulticide.

\section{Acknowledgments}

We thank Prof. V.G. Das, Director, Dayalbagh Educational Institute, for his encouragements. We also thankful to the Department of Science and Technology for the financial support (DST, C-24/ Soam Prakash) to conduct the research and to DST - FIST program (2003-2008) for providing laboratory facilities. G. Singh is indebted to University Grants Commission, New Delhi, for an award of Post Doctoral Fellowship (2009-2011).

Published: 20 October 2010

\section{References}

1. Knols BGJ, Bukhari T, Farenhorst M: Entomopathogenic fungi as the next generation control agents against malaria mosquitoes. Future Microbiology 2010, 5:339-341.

2. Prakash S, Singh G, Soni N, Sharma S: Pathogenicity of Fusarium oxysporum against the larvae of Culex quinquefasciatus (Say) and Anopheles stephensi (Liston) in laboratory. Parasitology 2010, Research DOI 10.1007/s00436-010-1911-1.

3. Scholte EJ, Ng'habi K, Kihonda J, Takken W, Paaijmans K, Abdulla S, Killeen GF, Knols BGJ: An entomopathogenic fungus for control of adult African malaria mosquitoes. Science 2005, 10:1641-164.

doi:10.1186/1475-2875-9-S2-P46

Cite this article as: Singh and Prakash: Efficacy of Lagenidium giganteum (Couch) metabolites for control Anopheles stephensi (Liston) a malaria vector. Malaria Journal 2010 9(Suppl 2):P46.

\section{Submit your next manuscript to BioMed Central} and take full advantage of:

- Convenient online submission

- Thorough peer review

- No space constraints or color figure charges

- Immediate publication on acceptance

- Inclusion in PubMed, CAS, Scopus and Google Scholar

- Research which is freely available for redistribution

Submit your manuscript at www.biomedcentral.com/submit 